\title{
Studies on Trueperella pyogenes isolated from an okapi (Okapia johnstoni) and a royal python (Python regius)
}

\author{
Marwa F. E. Ahmed', Mazen Alssahen² ${ }^{1}$ Christoph Lämmler ${ }^{2}$, Tobias Eisenberg ${ }^{3}$, Madeleine Plötz ${ }^{4}$ and \\ Amir Abdulmawjood ${ }^{4 *}$
}

\begin{abstract}
Background: The present study was designed to characterize phenotypically and genotypically two Trueperella pyogenes strains isolated from an okapi (Okapia johnstoni) and a royal python (Python regius).

Case presentation: The species identity could be confirmed by phenotypic properties, by MALDI-TOF MS analysis and by detection of $T$. pyogenes chaperonin-encoding gene cpn60 with a previously developed loop-mediated isothermal amplification (LAMP) assay. Furthermore, sequencing of the $16 \mathrm{~S}$ ribosomal RNA (rRNA) gene, the 16S-23S rDNA intergenic spacer region (ISR), the target genes rpoB encoding the $\beta$-subunit of bacterial RNA polymerase, tuf encoding elongation factor tu and plo encoding the putative virulence factor pyolysin allowed the identification of both $T$. pyogenes isolates at species level.

Conclusions: Both strains could be clearly identified as T. pyogenes. The T. pyogenes strain isolated in high number from the vaginal discharge of an okapi seems to be of importance for the infectious process; the T. pyogenes strain from the royal python could be isolated from an apparently non-infectious process. However, both strains represent the first isolation of $T$. pyogenes from these animal species.
\end{abstract}

Keywords: $16 \mathrm{~S}$ rRNA gene, 16S-23S rDNA intergenic spacer region, LAMP, MALDI-TOF MS, pyolysin, rpoB, tuf

\section{Background}

Trueperella pyogenes is worldwide considered as part of the commensal biota of skin and mucous membranes of the upper respiratory and urogenital tract of animals [1]. However, T. pyogenes is also an important opportunistic pathogen that causes mastitis, abortion and a variety of diverse pyogenic infections in livestock, including cattle, sheep, goats, horses, and pigs [2-4]. In cattle, T. pyogenes appears to be responsible for infections of the reproductive tract [5] and the mammary gland [6], as well as cases of pneumonia and liver abscessation of large

\footnotetext{
* Correspondence: amir.abdulmawjood@tiho-hannover.de

${ }^{4}$ Institute of Food Quality and Food Safety, Research Center for Emerging Infections and Zoonoses (RIZ), University of Veterinary Medicine Hannover, Bischofsholer Damm 15, D-30173 Hannover, Germany

Full list of author information is available at the end of the article
}

and small ruminants [7]. In swine, T. pyogenes is well known as a causative agent of different types of inflammation in various organs including the lung, heart, joints, mammary glands, and in the reproductive tract $[8,9]$. Furthermore, T. pyogenes could be found in companion animals [4]. One of the first reported cases in companion animals was an otitis externa detected in a cat and cystitis in a dog [10]. More recently, Wareth et al. [11] described a co-infection case of T. pyogenes with Brucella abortus in a cat and dog. Additionally, various wildlife animals could harbour T. pyogenes [3]. In 2010, Ülbegi-Mohyla et al. [12] characterized two $T$. pyogenes strains isolated from a bearded dragon and a gecko. Additionally, T. pyogenes infections were reported from a bison and from camels [13, 14], from goitered

C C The Author(s). 2020 Open Access This article is licensed under a Creative Commons Attribution 4.0 International License, which permits use, sharing, adaptation, distribution and reproduction in any medium or format, as long as you give appropriate credit to the original author(s) and the source, provide a link to the Creative Commons licence, and indicate if changes were made. The images or other third party material in this article are included in the article's Creative Commons licence, unless indicated otherwise in a credit line to the material. If material is not included in the article's Creative Commons licence and your intended use is not permitted by statutory regulation or exceeds the permitted use, you will need to obtain permission directly from the copyright holder. To view a copy of this licence, visit http://creativecommons.org/licenses/by/4.0/ The Creative Commons Public Domain Dedication waiver (http://creativecommons.org/publicdomain/zero/1.0/) applies to the data made available in this article, unless otherwise stated in a credit line to the data. 
gazelles [15] and from a white-tailed deer [16]. Likewise, some other sporadic cases of infectious diseases associated with $T$. pyogenes were described in a galago [17], in gray slender lorises $[18,19]$ and in a eurasian lynx $[20]$.

Besides conventional bacteriological methods for identifying T. pyogenes isolates, other new, fast and reliable techniques were described and utilized in this study: matrix-assisted laser desorption/ionization time-of-flight mass spectrometry (MALDI-TOF MS) [20-23], a loopmediated isothermal amplification (LAMP) assay [24] and $16 \mathrm{~S}$ rRNA gene sequencing $[25,26]$.
The present study was designed to identify and further characterize $T$. pyogenes isolated from wildlife animals phenotypically and genotypically. To the best of our knowledge, the present study provides a first detailed description of $T$. pyogenes recovered from an okapi and a royal python.

\section{Case presentation}

As part of routine examination and diagnostics performed on zoo animals at Frankfurt Zoo (Frankfurt am Main, Germany) in 2019, T. pyogenes 24398 was isolated

Table 1 Biochemical properties of T. pyogenes 24398 (okapi), T. pyogenes 171003246 (royal python) and type strain T. pyogenes DSM $20630^{\top}$

\begin{tabular}{|c|c|c|c|}
\hline Biochemical properties & $\begin{array}{l}\text { T. pyogenes } \\
24398 \\
\text { (okapi) }\end{array}$ & $\begin{array}{l}\text { T. pyogenes } \\
171003246 \\
\text { (royal python) }\end{array}$ & T. pyogenes ${ }^{a}$ DSM $20630^{\top}$ \\
\hline Haemolysis on SBA & + & + & + \\
\hline \multicolumn{4}{|l|}{ CAMP-like hemolytic reaction with ${ }^{c}$ : } \\
\hline Staphylococcus aureus & + & + & + \\
\hline Streptococcus agalactiae & - & - & - \\
\hline Rhodococcus hoagii & + & + & + \\
\hline Reverse CAMP reaction & - & - & - \\
\hline Nitrate reduction & - & - & - \\
\hline Pyrazinamidase & - & - & - \\
\hline Pyrrolidonyl Arylamidase & + & + & + \\
\hline Alkaline phosphatase & + & + & + \\
\hline$\beta$-Glucuronidase ( $\beta$-GUR) & + & + & + \\
\hline$\beta$-Galactosidase ( $\beta$-GAL) & + & + & + \\
\hline a-Glucosidase ( a-GLU) & + & + & + \\
\hline N-Acetyl- $\beta$-glucosaminidase ( $\beta$-NAG) & + & + & + \\
\hline Esculin ( $\beta$-glucosidase) & - & - & - \\
\hline Urease & - & - & - \\
\hline Gelatine & + & + & + \\
\hline \multicolumn{4}{|l|}{ Fermentation of: } \\
\hline Glucose & + & + & + \\
\hline Ribose & + & + & + \\
\hline Xylose & + & + & + \\
\hline Mannitol & - & - & - \\
\hline Maltose & + & + & + \\
\hline Lactose & + & + & + \\
\hline Saccharose & - & + & - \\
\hline Glycogen & + & + & + \\
\hline Catalase & - & - & - \\
\hline Serolysis on Loeffler agar & + & + & + \\
\hline $\begin{array}{l}\text { Identification \% according to } \\
\text { API-Coryne test System }\end{array}$ & 99.9 & 99.9 & 99.9 \\
\hline
\end{tabular}




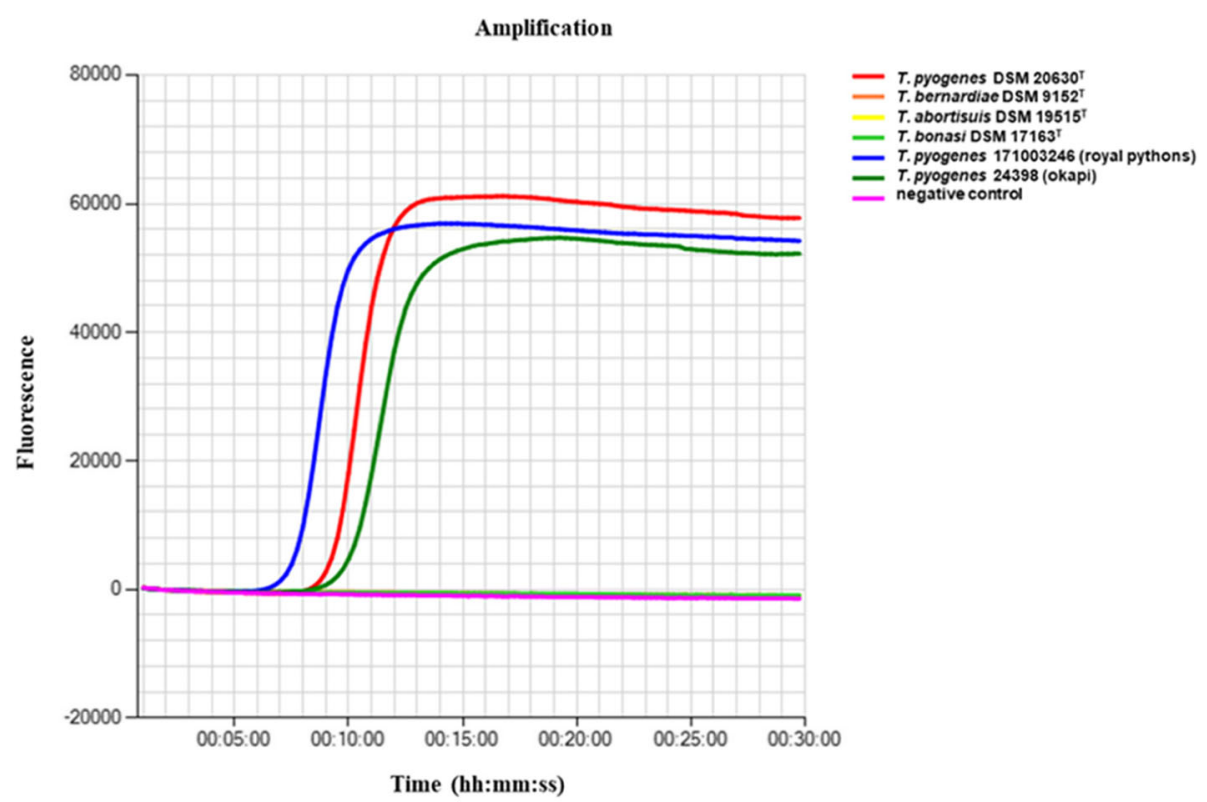

Fig. 1 Positive LAMP assay of T. pyogenes 24398 (okapi), T. pyogenes 171003246 (royalpython), T. pyogenes DSM 20630', the LAMP negative control strains T. abortisuis DSM 19515 ${ }^{\top}$, T. bernardiaeDSM $9152^{\top}$ and T. bonasi DSM $17163^{\top}$, and a negative control

from a vaginal discharge of an okapi (Okapia johnstoni) in high numbers $(+++)$, together with Enterobacter cloacae (+) and Pasteurella spp. (+). The initial bacteriology analysis for T. pyogenes 24398 was performed at Hessian State Laboratory (LHL) Gießen, Germany. As a result of post-mortem examination conducted in 2017, T. pyogenes 171003246 was recovered in low numbers $(+)$ from a kidney of a seven-year-old female royal python (Python regius). The python was found dead in a bird park in Hesse (Germany) and was $107 \mathrm{~cm}$ in length and weighted $1.23 \mathrm{~kg}$. In addition, Escherichia coli $(+), \alpha-$ hemolytic streptococci $(+)$, Corynebacterium spp. (+) and Clostridium sardiniense $(+)$ were cultured from the python specimen. The post-mortem analysis of the royal python revealed a good body condition and in the throat and head area a $15 \mathrm{~cm}$ lung edema and swelling, possibly caused by traumatic reasons. The post-mortem examination and the initial bacteriology analysis were also performed at Hessian State Laboratory. Both T. pyogenes strains were further investigated phenotypically and genotypically.

\section{Phenotypic characterization}

A phenotypic characterization was performed using conventional cultural and biochemical assays as previously described $[12,18,20,27]$ and the API-Coryne test System (BioMérieux, Nürtingen, Germany) in accordance with the manufacturer's instructions. Furthermore, the bacterial isolates were identified by MALDI-TOF MS using a Microflex LT (Bruker Daltonik GmbH, Bremen, Germany) instrument and MBT Compass Explorer 4.1 software (Bruker Daltonik GmbH). Sample preparation was carried out in accordance with the manufacturer's instructions using the direct transfer method. Briefly, one microbial colony was first smeared in duplicate onto spots of the MALDI target MSP 96 target (MicroScout Target plate; Bruker Daltonik $\mathrm{GmbH}$ ) with sterile toothpicks. The air-dried bacteria were overlaid with $1 \mu \mathrm{l}$ of an $\alpha$-cyan 4-hydroxycinnamic acid matrix solution

Table 2 Results of LAMP including detection time and annealing temperature of the tested isolate, positive and negative control

\begin{tabular}{|c|c|c|c|c|c|c|c|}
\hline Sample ID & $\begin{array}{l}\text { T. pyogenes } \\
24398\end{array}$ & $\begin{array}{l}T . \\
\text { pyogenes } \\
171003246\end{array}$ & $\begin{array}{l}\text { T. pyogenes DSM } \\
20630^{\top}\end{array}$ & $\begin{array}{l}\text { T. abortisuis DSM } \\
19515^{\mathrm{T}}\end{array}$ & $\begin{array}{l}T . \\
\text { bernardiae } \\
\text { DSM } \\
9152^{\top}\end{array}$ & $\begin{array}{l}\text { T. bonasi DSM } \\
17163^{\top}\end{array}$ & $\begin{array}{l}\text { HPLC water and Master } \\
\text { mix }\end{array}$ \\
\hline Result & +ve & +ve & +ve & -ve & -ve & -ve & -ve \\
\hline $\begin{array}{l}\text { Detection } \\
\text { time } \\
\text { hh:mm:ss }\end{array}$ & 00:11:00 & 00:08:30 & 00:10:00 & 0 & 0 & 0 & 0 \\
\hline Annealing & 89.6 & 89.4 & 89.9 & 0 & 0 & 0 & 0 \\
\hline
\end{tabular}

+ve: Positive, -ve: Negative, ${ }^{\top}$ :type strain 


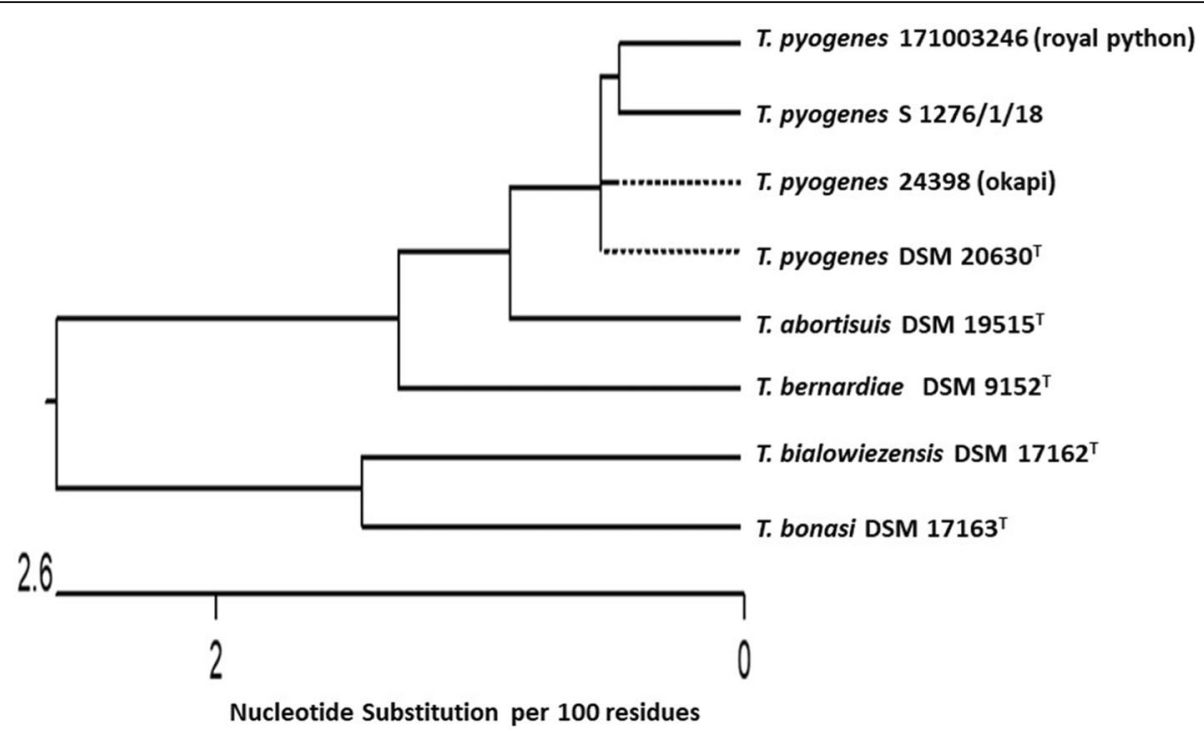

Fig. 2 Phylogenetic analysis based on nucleotide sequences of $16 \mathrm{~S}$ rRNA gene of the investigated T. pyogenes 24398 and T. pyogenes 171003246 isolated from okapi and royal python compared with the type strain T. pyogenes DSM 20630 and T. pyogenes S 1276/1/18 isolated from a eurasian lynx, T. abortisuis DSM 19515' ${ }^{\top}$, T. bernardiae DSM $9152^{\top}$, T. bialowiezensis DSM $17162^{\top}$, and T. bonasi DSM $17163^{\top}$

(HCCA, in $50 \%$ acetonitrile and $2.5 \%$ trifluoroacetic acid in pure water) followed by drying and loading into the mass spectrometer.

\section{Genotypic properties}

The genomic DNA of both isolates and the type strains T. pyogenes DSM $20630^{\mathrm{T}}$ (pig), T. abortisuis DSM $19515^{\mathrm{T}}$ (placenta of sow after abortion), T. bernardiae DSM $9152^{\mathrm{T}}$ (human blood) and T. bonasi DSM $17163^{\mathrm{T}}$ (european bison) were extracted using the DNeasy blood and tissue kit (Qiagen GmbH, Hilden, Germany), in accordance with the manufacturer's instructions. The concentration and purity of DNA were measured by utilizing a Nano Drop spectrophotometer (ND1000; Thermo Fisher Scientific GmbH, Dreieich, Germany).

The detection of gene сри60 of T. pyogenes was performed using a previously designed loop-mediated isothermal amplification (LAMP) assay [24] with a portable real-time fluorometer (Genie $\mathrm{II}^{\circ}$, OptiGene Ltd, Horsham, UK) and the reference strains T. pyogenes DSM $20630^{\mathrm{T}}$, T. abortisuis DSM $19515^{\mathrm{T}}$, T. bernardiae DSM $9152^{\mathrm{T}}$ and T. bonasi DSM $17163^{\mathrm{T}}$.

Both $T$. pyogenes isolates were also evaluated by $\mathrm{PCR}$ for the presence of five genomic targets: 16S rRNA gene (16S), 16S-23S rDNA intergenic spacer region (ISR), the $\beta$-subunit of bacterial RNA polymerase encoding gene $r p o \mathrm{~B}$, the elongation factor tu encoding gene tuf, and pyolysin encoding gene plo. The sequence of the oligonucleotide primers and PCR conditions were previously described by Hassan et al. [25], Ülbegi-Mohyla et al. [12], Hijazin et al. [27], Eisenberg et al. [18], Wickhorst et al. [28], Wickhorst et al. [23], Alssahen et al. [20].
The PCR products were purified and sequenced by Eurofins Umwelt Nord GmbH (Göttingen, Germany). The obtained sequences were analyzed via the cluster method of the MegAlign program (DNASTAR Inc., ver. 15, Madison, WI, USA) by comparing with the nucleotide sequences of $16 \mathrm{~S}$ rRNA, ISR, $r p o \mathrm{~B}$, tuf and plo from different Trueperella reference strains. Moreover, the resulting amino acid sequences of pyolysin of both $T$. pyogenes isolates were compared with the respective sequences of pyolysin of T. pyogenes DSM $20630^{\mathrm{T}}$, closely related pore-forming toxins of genus Arcanobacterium and with other bacterial pore-forming toxins. All the nucleotide and amino acid sequences were obtained from the NCBI GenBank.

\section{Discussion and Conclusion}

Both $T$. pyogenes strains investigated in the present study showed a narrow zone of complete hemolysis on 5\% sheep blood agar and CAMP-like reactions in the staphylococcal $\beta$-hemolysin zone with Rhodococcus hoagii as an indicator strain. The conventional biochemical properties and the results of the commercial identification system revealed almost identical results to previously investigated $T$. pyogenes of various origins and $T$. pyogenes DSM $20630^{\mathrm{T}}[12,18,20,27]$ (Table. 1). The $T$. pyogenes isolates yielded positive reactions for pyrrolidonyl arylamidase, alkaline phosphatase, $\beta$-glucuronidase, $\beta$-galactosidase, $\alpha$-glucosidase and $\mathrm{N}$-acetyl- $\beta$-glucosaminidase and negative reactions for nitrate reduction and pyrazinamidase. Additionally, the isolates hydrolyzed gelatine, but not esculin and urea. The isolates also fermented D-glucose, D-ribose, D-xylose, D-maltose, D- 

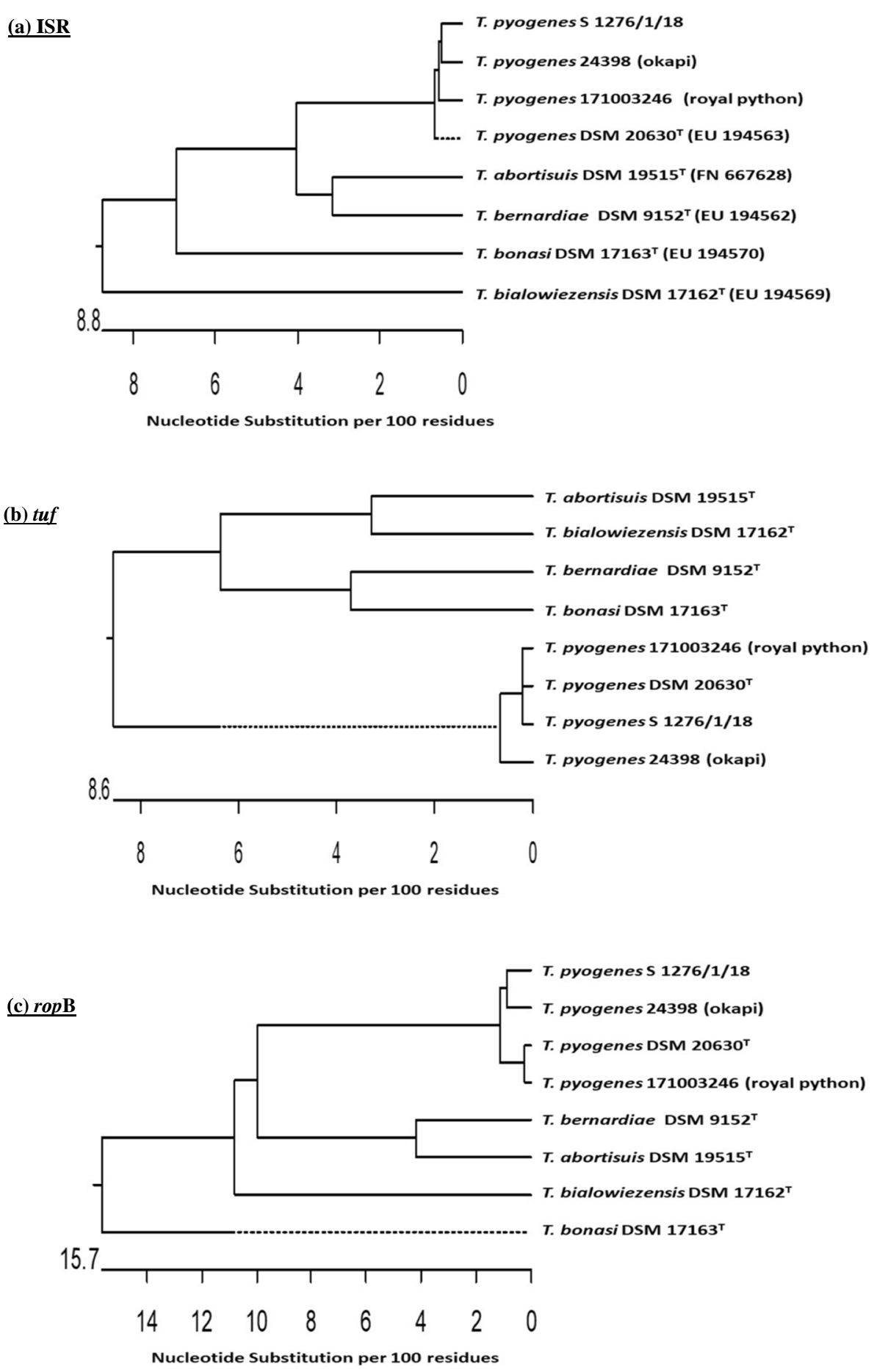

Fig. 3 Phylogenetic analyses based on ISR (a), tuf (b) and ropB (c) nucleotide sequences of the investigated T. pyogenes 24398 and T. pyogenes 171003246 and T. pyogenes S 1276/1/18 isolated from a eurasian lynx and the control strains, T. pyogenes DSM 20630, T. abortisuis DSM 19515,$T$. bernardiae DSM $9152^{\top}$, T. bialowiezensis DSM $17162^{\top}$, and T. bonasi DSM $17163^{\top}$

lactose and glycogen, but not D-mannitol. T. pyogenes 24398 fermented D-saccharose; however, T. pyogenes 171003246 was D-saccharose negative. In addition, both isolates showed a negative catalase reaction and a positive reaction on Löffler agar (Table 1). A postitive reaction on Löffler agar is typical for T. pyogenes and widely used for phenotypic identification of this species $[2,18]$. 


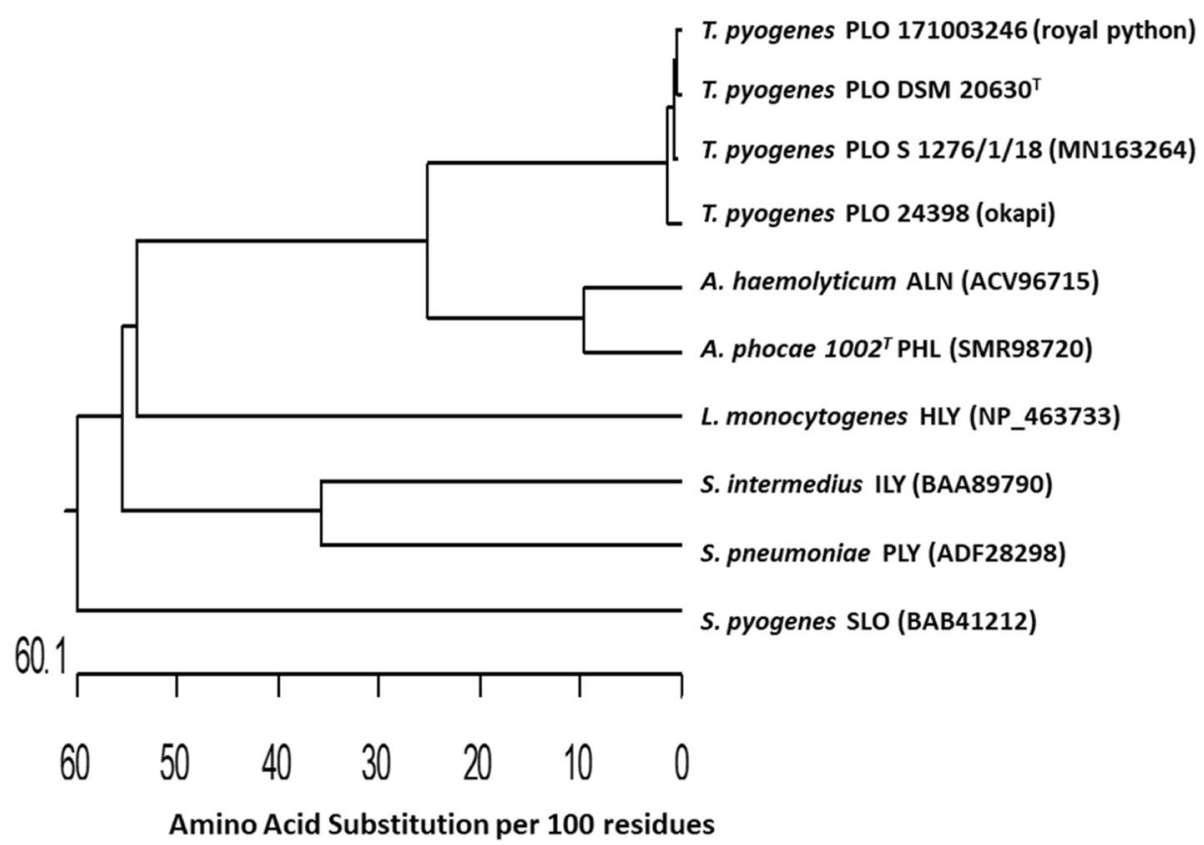

Fig. 4 Phylogenetic relationships among amino acid sequences of PLO of the investigated T. pyogenes 24398 and T. pyogenes 171003246, PLO of type strain T. pyogenes $20630^{\top}, T$. pyogenes S 1276/1/18 isolated from a eurasian lynx, ALN of A. haemolyticum, PHL of A. phocae, HLY of L. monocytogenes, PLY of S. pneumoniae

Moreover, MALDI-TOF MS identified T. pyogenes 24398 and $T$. pyogenes 171003246 with log score values of 2.35 and 2.29 for the first hit and log score values of 2.28 and 1.9 for the second hit, respectively (data not shown). These log score values confirmed, in accordance with the current decision rules of the manufacturer, the species designation. Comparable to the present results, MALDI-TOF MS had already been shown to be a rapid and reliable technique for identifying bacteria of genera Arcanobacterium and Trueperella, including T. pyogenes [20, 21].

The previously described cpn60-specific LAMP assay could successfully be used to identify the species-specific gene cpn60 of T. pyogenes 24,398 and T. pyogenes 171 , 003,246 in the present investigation. This was comparable to the LAMP assay for detecting gene cpn60 of the previously described T. pyogenes of various origins [24], a $T$. pyogenes strain isolated from an adult roebuck (Capreolus capreolus) [23], and a T. pyogenes strain isolated from a eurasian lynx $(\operatorname{Lynx} \operatorname{lynx})$ [20]. The results of the cpn60 LAMP assay are shown in Fig. 1; Table 2.

The oligonucleotide primers, 16SUNI-L and 16SUNI$\mathrm{R}$, were used for amplifying of $16 \mathrm{~S}$ rRNA gene of the investigated $T$. pyogenes isolates. The nucleotide sequence data of T. pyogenes 24398 (GenBank accession numbers: MN946520) and T. pyogenes 171003246 (MN712476) were compared with type strain $T$. pyogenes DSM $20630^{\mathrm{T}}$ (AAC45754) and with the previously described strain T. pyogenes S 1276/1/18 isolated from a eurasian lynx (MN135984), T. abortisuis DSM $19515^{\mathrm{T}}$ (FN667628), T. bernardiae DSM 9152 ${ }^{\mathrm{T}}$ (X79224), T. bialowiezensis DSM $17162^{\mathrm{T}}$ (EU194569), and T. bonasi DSM $17163^{\mathrm{T}}$ (EU194570). The nucleotide sequence data of T. pyogenes 24398 and T. pyogenes 171003246 revealed a sequence homology of $98.9 \%$ among both strains, a sequence homology of $99.5 \%$ and $98.7 \%$ with T. pyogenes DSM $20,630^{\mathrm{T}}$, and a sequence homology of 99.9\% and $99.1 \%$ with $T$. pyogenes S1276/1/18, respectively. The control strains of genus Trueperella yielded a sequence homology to both $T$. pyogenes isolates $\leq 98.7 \%$ (Fig. 2).

Both strains T. pyogenes 24398 and T. pyogenes 171003246 were further identified by sequencing ISR, the genes tuf and rpoB and the putative virulence factor pyolysin encoding gene plo. T. pyogenes 24398 and T. pyogenes 171003246 showed sequence similarities of ISR (MN947249, MN724920) of $99.8 \%$ and $98.9 \%$ with $T$. pyogenes DSM $20630^{\mathrm{T}}$ (EU194563) and 100\% and $99.8 \%$ with $T$. pyogenes S 1276/1/18 (MN164031), respectively with $98.5 \%$ identity between both strains. The additionally investigated gene tuf (MN956808, MN741111) showed a sequence similarity of $99.6 \%$ and $99.7 \%$ with $T$. pyogenes DSM 20630 ${ }^{\mathrm{T}}$ (HG941716), and 99.6\% and 99.7\% with T. pyogenes S 1276/1/18 (MN163266), respectively; gene rpoB (MN956807, MN741109), a sequence similarity of $99.8 \%$ and $98.3 \%$ with $T$. pyogenes DSM $20630^{\mathrm{T}}$ (FN550375), and $98.8 \%$ and $98.3 \%$ with $T$. pyogenes S 1276/1/18 (MN163265), respectively, and 
gene plo (MN956806, MN741110), a sequence similarity of $99.5 \%$ with $T$. pyogenes DSM $20630^{\mathrm{T}}$ (U84782) for both isolates, and 99.1\% with T. pyogenes S 1276/1/18 (MN163264) for both isolates.

Dendrograms of the ISR, tuf and rpoB genes are presented in Fig. 3.

A phylogenetic analysis of the amino acid sequences of pyolysin (PLO) encoded by gene plo of $T$. pyogenes 24398 (MN956806), and T. pyogenes 171003246 (MN741110) PLO of type strain T. pyogenes DSM $20630^{\mathrm{T}}$ (AAC45754), PLO of T. pyogenes S 1276/1/18 (MN163264), arcanolysin (ALN) of Arcanobacterium haemolyticum (ACV96715), phocaelysin (PHL) of Arcanobacterium phocae $10002^{\mathrm{T}}$ (SMR98720), listeriolysin O (HLY) of Listeria monocytogenes (NP_463733), intermedilysin (ILY) of Streptococcus intermedius (BAA89790), pneumolysin (PLY) of Streptococcus pneumoniae (ADF28298) and streptolysin O (SLO) of Streptococcus pyogenes (BAB41212). The results showed an amino acid similarity of $99.5 \%$ for both $T$. pyogenes 24,398 and $T$. pyogenes 171003246 with PLO of T. pyogenes DSM $20630^{\mathrm{T}}$ and $99.1 \%$ with PLO of T. pyogenes S 1276/1/18 (Fig. 4).

T. pyogenes 24398 was isolated in high numbers from vaginal discharge of an okapi and seems to be responsible for the infectious process; T. pyogenes 171003246 was isolated from a non-infectious process of a royal python suffering from a throat swelling, possibly caused by trauma. Both $T$. pyogenes isolates were identified by a biochemical test, LAMP and MALDI-TOF MS. The genomic targets of the two isolates, 16S rRNA gene, ISR, tuf, rpoB and plo were sequenced and compared to the respective targets of reference and other strains. Thus, the report is the first to provide a detailed characterization of $T$. pyogenes strains of these origin.

\section{Abbreviations}

MALDI-TOF MS: Matrix-assisted laser desorption/ionization time-of-flight mass spectrometry; LAMP: Loop-mediated isothermal amplification; rRNA: Ribosomal RNA; ISR: 16S-23S rDNA intergenic spacer region; CAMP test: Christie-Atkins-Munch-Peterson-test; DSM: German Collection of Microorganisms; ALN: Arcanolysin; PHL: Phocaelysin; HLY: Listeriolysin O; ILY: Intermedilysin; PLY: Pneumolysin; SLO: Streptolysin O

\section{Acknowledgements}

Not applicable.

\section{Authors' contributions}

MFEA, MA, CL, AA and MP contributed to the design of the study, collected and analysed the data. TE performed the initial examination of the isolates. MFEA, AA and MP drafted the manuscript. All authors read and approved the final manuscript.

\section{Funding}

Open access funding provided by Projekt DEAL.

\section{Availability of data and materials}

The datasets generated during the current study are available in the NBCI GenBank repository, under the accession number: MN741109, MN741110, MN741111, MN956806, MN956807 and MN956808.

\section{Ethics approval and consent to participate}

This study did not require official or institutional ethical approval. The material was collected post mortem and/or during routine diagnosis. According to competent authorities, this kind of research does not require ethics approval or general approval with respect to German law.

\section{Consent for publication}

Not applicable.

\section{Competing interests}

The authors declare that they have no competing interests.

\section{Author details}

${ }^{1}$ Hygiene and Zoonoses Department, Faculty of Veterinary Medicine, Mansoura University, Elgomhoria Street 60, 35516 Mansoura, Egypt. ${ }^{2}$ Institut für Hygiene und Infektionskrankheiten der Tiere, Justus-Liebig-Universität Gießen, Frankfurterstraße 85-91, D-35392 Gießen, Germany. ${ }^{3}$ Landesbetrieb Hessisches Landeslabor (LHL), Schubertstraße 60, D-35392 Gießen, Germany. ${ }^{4}$ Institute of Food Quality and Food Safety, Research Center for Emerging Infections and Zoonoses (RIZ), University of Veterinary Medicine Hannover, Bischofsholer Damm 15, D-30173 Hannover, Germany.

Received: 9 June 2020 Accepted: 3 August 2020

Published online: 14 August 2020

References

1. Rzewuska M, Kwiecien E, Chrobak-Chmiel D, Kizerwetter-Swida M, Stefanska I, Gierynska M. Pathogenicity and virulence of Trueperella pyogenes: a review. Int J Mol Sci. 2019;20(11):2737.

2. Lämmler $\mathrm{C}$, Hartwigk H. Actinomyces pyogenes und Arcanobacterium haemolyticum. In: Handbuch der bakteriellen Infektionen bei Tieren. 2nd edn: Gustav Fischer: Jena 1995: 196-240.

3. Jost BH, Billington SJ. Arcanobacterium pyogenes: molecular pathogenesis of an animal opportunist. Antonie Van Leeuwenhoek. 2005;88(2):87-102.

4. Ribeiro MG, Risseti RM, Bolanos CAD, Caffaro KA, de Morais ACB, Lara GHB, et al. Trueperella pyogenes multispecies infections in domestic animals: a retrospective study of 144 cases (2002 to 2012). Vet Quart. 2015:35(2):82-7.

5. Tamai IA, Mohammadzadeh A, Salehi TZ, Mahmoodi P. Genomic characterisation, detection of genes encoding virulence factors and evaluation of antibiotic resistance of Trueperella pyogenes isolated from cattle with clinical metritis. Antonie Van Leeuwenhoek. 2018;111(12):244153.

6. Ishiyama D, Mizomoto T, Ueda C, Takagi N, Shimizu N, Matsuura Y, et al. Factors affecting the incidence and outcome of Trueperella pyogenes mastitis in cows. J Vet Med Sci. 2017;79(3):626-31.

7. Rogovskyy AS, Lawhon S, Kuczmanski K, Gillis DC, Wu J, Hurley H, et al. Phenotypic and genotypic characteristics of Trueperella pyogenes isolated from ruminants. J Vet Diagn Invest. 2018:30(3):348-53.

8. Jarosz LS, Gradzki Z, Kalinowski M. Trueperella pyogenes infections in swine: clinical course and pathology. Pol J Vet Sci. 2014;17(2):395-404.

9. Dong WL, Liu L, Odah KA, Atiah LA, Gao YH, Kong LC, et al. Antimicrobial resistance and presence of virulence factor genes in Trueperella pyogenes isolated from pig lungs with pneumonia. Trop Anim Health Pro. 2019;51(7): 2099-103.

10. Billington SJ, Post KW, Jost BH. Isolation of Arcanobacterium (Actinomyces) pyogenes from cases of feline otitis externa and canine cystitis. J Vet Diagn Invest. 2002;14(2):159-62

11. Wareth G, El-Diasty M, Melzer F, Murugaiyan J, Abdulmawjood A, Sprague LD, et al. Trueperella pyogenes and Brucella abortus coinfection in a dog and a cat on a dairy farm in Egypt with recurrent cases of mastitis and abortion. Vet Med Int. 2018;2018:2056436.

12. Ülbegi-Mohyla H, Hijazin M, Alber J, Lämmler C, Hassan AA, Abdulmawjood A, et al. Identification of Arcanobacterium pyogenes isolated by post mortem examinations of a bearded dragon and a gecko by phenotypic and genotypic properties. J Vet Sci. 2010;11(3):265-7.

13. Wareth G, Murugaiyan J, Khater DF, Moustafa SA. Subclinical pulmonary pathogenic infection in camels slaughtered in Cairo, Egypt. J Infect Dev Countr. 2014:8(7):909-13.

14. Tarazi YH, Al-Ani FK. An outbreak of dermatophilosis and caseous lymphadenitis mixed infection in camels (Camelus dromedaries) in Jordan. J Infect Dev Countr. 2016;10(5):506-11. 
15. CCeçen G, Buyukcangaz EK, Caliskan UG, Cangul TI, Akdesir E. Interdigital necrobacillosis associated with Trueperella pyogenes in Goitered Gazelles (Gazella Subgutturosa). J Zoo Wildlife Med. 2018;49(2):429-34.

16. Cohen BS, Belser EH, Keeler SP, Yabsley MJ, Miller KV. Isolation and genotypic characterization of Trueperella (Arcanobacterium) pyogenes recovered from active cranial abscess Infections of Male White-Tailed Deer (Odocoileus Virginianus). J Zoo Wildlife Med. 2015;46(1):62-7.

17. Salleng KJ, Burton BJ, Apple TM, Sanchez S. Isolation of Trueperella pyogenes in a case of thoracic and abdominal abscess in a galago (Otolemur garnettii). J Med Primatol. 2016;45(4):198-201.

18. Eisenberg T, Nagib S, Hijazin M, Alber J, Lämmler C, Hassan AA, et al. Trueperella pyogenes as cause of a facial abscess in a grey slender loris (Loris lydekkerianus nordicus) - a case report. Berl Münch Tierärztl. 2012;125(9-10): 407-10.

19. Nagib S, Glaeser SP, Eisenberg T, Sammra O, Lämmler C, Kämpfer $P$, et al. Fatal infection in three Grey Slender Lorises (Loris lydekkerianus nordicus) caused by clonally related Trueperella pyogenes. BMC Vet Res. 2017;13:273.

20. Alssahen M, Peters M, Rau J, Hassan AA, Sammra O, Lämmler C, et al. Phenotypic and genotypic approach to characterize a Trueperella pyogenes strain isolated from an Eurasian Lynx (Lynx lynx). Berl Münch Tierärztl. 2020 https://doi.org/10.2376/0005-9366-19037.

21. Hijazin M, Hassan AA, Alber J, Lämmler C, Timke M, Kostrzewa M, et al. Evaluation of matrix-assisted laser desorption ionization-time of flight mass spectrometry (MALDI-TOF MS) for species identification of bacteria of genera Arcanobacterium and Trueperella. Vet Microbiol. 2012;157(1-2):243-5.

22. Randall LP, Lemma F, Koylass M, Rogers J, Ayling RD, Worth D, et al. Evaluation of MALDI-TOF as a method for the identification of bacteria in the veterinary diagnostic laboratory. Res Vet Sci. 2015;101:42-9.

23. Wickhorst JP, Hassan AA, Sheet OH, Eisenberg T, Sammra O, Alssahen M et al. Trueperella pyogenes isolated from a brain abscess of an adult roebuck (Capreolus capreolus). Folia Microbiol. 2018;63(1):17-22.

24. Abdulmawjood A, Wickhorst J, Hashim O, Sammra O, Hassan AA, Alssahen $M$, et al. Application of a loop-mediated isothermal amplification (LAMP) assay for molecular identification of Trueperella pyogenes isolated from various origins. Mol Cell Probe. 2016;30(4):205-10.

25. Hassan AA, Ülbegi-Mohyla H, Kanbar T, Alber J, Lämmler C, Abdulmawjood A, et al. Phenotypic and genotypic characterization of Arcanobacterium haemolyticum isolates from infections of horses. J Clin Microbiol. 2009;47(1): $124-8$.

26. Moreno LZ, Matajira CEC, da Costa BLP, Ferreira TSP, Silva GFR, Dutra MC, et al. Characterization of porcine Trueperella pyogenes by matrix-assisted laser desorption ionization-time of flight mass spectrometry (MALDI-TOF MS), molecular typing and antimicrobial susceptibility profiling in Sao Paulo State. Comp Immunol Microb. 2017;51:49-53.

27. Hijazin M, Ülbegi-Mohyla H, Alber J, Lämmler C, Hassan AA, Abdulmawjood $A$, et al. Molecular identification and further characterization of Arcanobacterium pyogenes isolated from bovine mastitis and from various other origins. J Dairy Sci. 2011;94(4):1813-9.

28. Wickhorst JP, Sammra O, Hassan AA, Alssashen M, Lämmler C, Prenger-

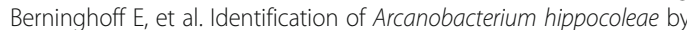
MALDI-TOF MS analysis and by various genotypical properties. Res Vet Sci. 2017:115:10-2

\section{Publisher's Note}

Springer Nature remains neutral with regard to jurisdictional claims in published maps and institutional affiliations.

Ready to submit your research? Choose BMC and benefit from:

- fast, convenient online submission

- thorough peer review by experienced researchers in your field

- rapid publication on acceptance

- support for research data, including large and complex data types

- gold Open Access which fosters wider collaboration and increased citations

- maximum visibility for your research: over $100 \mathrm{M}$ website views per year

At $\mathrm{BMC}$, research is always in progress.

Learn more biomedcentral.com/submissions 